\title{
Analisis Daya Saing Komparatif dan Kompetitif Ekspor Komoditas Batu Bara Tiga Negara Berkembang (Indonesia, Afrika Selatan dan Kolombia)
}

\author{
Sifa Yulia ${ }^{1 *}$, Ika Chandriyanti ${ }^{2)}$ \\ 1) 2) Economics and Development Studies, Lambung Mangkurat University, Banjarmasin, Indonesia \\ *E-mail corresponding author: $1710311220046 @$ mhs.ulm.ac.id
}

Received: 26-07-2021;

Accepted: 07-09-2021;

Available online: 31-10-2021

\section{Ecoplan}

Vol. 4 No. 2, Oktober 2021, hlm 99-110

\section{ISSN p: 2620-6102 e: 2615-5575}

Abstract - Coal is a fuel made from fossils, which hold an essential part of the energy for power plants and serves as a staple fuel for steel and cement production. Indonesia, South Africa, and Colombia are developing countries that took part in the largest coal exporters in the world. The purpose of this study is to analyze the three developing countries in coal exporting competitiveness, Indonesia, South Africa, and Colombia, in terms of comparative advantage or competitive advantage and times of the trade specialization index, as well as compare the exports and imports of coal from the three countries and export developments. This study will be using secondary data within a period of fifteen years $(2004-2018)$. The data analysis methods used in this study are based on the Balassa Index of Revealed Comparative Advantage (RCA) and the Trade Specialization Index (TSI). The research from RCA showed that Indonesia doesn't have a comparative advantage in contrast to South Africa, but Indonesia has a comparative advantage collated with Colombia. Based on the study held by TSI, the three developing countries are presumed to have strong competitiveness and tend to succeed in becoming coal exporting countries.

Abstrak - Batu bara adalah bahan bakar fosil yang merupakan sumber energi terpenting untuk pembangkit listrik dan berfungsi sebagai bahan bakar pokok untuk produksi baja dan semen. Indonesia, Afrika Selatan dan Kolombia merupakan negara berkembang yang menjadi salah satu eksportir batu bara terbanyak di dunia. Tujuan penelitian ini adalah untuk menganalisis daya saing ekspor komoditas batu bara pada tiga negara berkembang yaitu Indonesia, Afrika Selatan dan Kolombia dari sisi keunggulan komparatif atau keunggulan kompetitif dan dari sisi indeks spesialisasi perdagangan, serta membandingkan ekspor dan impor batu bara ketiga negara tersebut dan perkembangan ekspor batu baranya. Penelitian ini menggunakan data sekunder dengan periode selama lima belas tahun yaitu tahun 2004 - 2018. Metode analisis data yang digunakan dalam penelitian ini adalah Balassa Index atau Revealed Comparative Advantage (RCA) dan Indeks Spesialisasi Perdagangan (ISP). Hasil perhitungan RCA menunjukkan bahwa Indonesia tidak memiliki keunggulan komparatif jika dibandingkan dengan Afrika Selatan, namun Indonesia memiliki keunggulan komparatif jika dibandingkan dengan Kolombia. Berdasarkan analisis ISP menunjukkan ketiga negara berkembang tersebut memiliki daya saing yang kuat dan cenderung menjadi negara pengeskpor komoditas batu bara.

Kata Kunci : Daya Saing, Ekspor Batu Bara, Balassa Index, Revealed Comparative Advantage, Indeks Spesialisasi Perdagangan 


\section{PENDAHULUAN}

Untuk mengetahui keberhasilan perdagangan ekspor suatu wilayah dapat dilihat dari daya saingnya. Daya saing adalah suatu konsep umum yang digunakan dalam ekonomi, yang merujuk kepada persaingan pasar terhadap keberhasilan persaingan perdagangan dalam ekspor internasional. Kegiatan ekspor mempunyai peran penting dalam perekonomian di Indonesia, yaitu penyumbang pendapatan negara dan menambah devisa. Salah satu yang berperan dalam kegiatan ekspor di Indonesia adalah pertambangan batu bara.

Batu bara adalah salah satu ekspor unggulan Indonesia sampai saat ini, hal ini dikarenakan Indonesia masih memiliki banyak cadangan batu bara dan dipengaruhi oleh permintaan domestik maupun internasional yang masih cukup tinggi, sehingga menjadikan batu bara sebagai salah satu komoditas utama penyumbang ekspor dan memberikan kontribusi yang cukup besar bagi perekonomian negara. Indonesia bukan satu-satunya negara pengekspor batu bara, tetapi ada Afrika Selatan dan Kolombia yang juga menjadikan batu bara sebagai salah satu ekspor unggulannya. Hal ini menyebabkan terjadinya persaingan ekspor batu bara oleh ketiga negara berkembang tersebut (Indonesia-Investments, 2018).

Mengutip data Kementerian Energi dan Sumber Daya Mineral (ESDM), proyeksi produksi batu bara pada tahun 2020 - 2024 mengalami peningkatan. Di tahun 2020 produksi ditargetkan sebesar 550 juta ton dengan alokasi ekspor 395 juta ton dan domestik 155 juta ton. Di tahun 2021 produksi ditargetkan sebesar 609 juta ton yang terbagi untuk ekspor 441 juta ton dan domestik 168 juta ton. Kemudian pada tahun 2022 sebesar 618 juta ton untuk ekspor 441 juta ton dan domestik 177 juta ton. Selanjutnya di 2023 produksi sebesar 625 juta ton untuk ekspor 441 juta ton dan domestik 184 juta ton. Serta di 2024 produksi ditargetkan sebesar 628 juta ton untuk ekspor 441 juta ton dan domestik 187 juta (Utami, 2020).

Tabel 1. Produksi, Ekspor dan Pengunaan Batu Bara Indonesia

\begin{tabular}{cccc}
\hline Tahun & $\begin{array}{c}\text { Produksi } \\
\text { (dalam juta ton) }\end{array}$ & $\begin{array}{c}\text { Ekspor } \\
\text { (dalam juta ton) }\end{array}$ & $\begin{array}{c}\text { Konsumsi Domestik } \\
\text { (dalam juta ton) }\end{array}$ \\
\hline 2007 & 217 & 163 & 61 \\
2008 & 240 & 191 & 49 \\
2009 & 254 & 198 & 56 \\
2010 & 275 & 210 & 65 \\
2011 & 353 & 287 & 66 \\
2012 & 412 & 345 & 67 \\
2013 & 474 & 402 & 72 \\
2014 & 458 & 382 & 76 \\
2015 & 461 & 375 & 86 \\
2016 & 456 & 365 & 91 \\
2017 & 461 & 354 & 97 \\
2018 & 548,58 & 356,5 & 115 \\
\hline
\end{tabular}

Sumber: Indonesian Coal Mining Association (APBI) \& Ministry of Energy and Mineral Resources (APBI-ICMA, 2021)

Mengutip data Kementerian Energi dan Sumber Daya Mineral (ESDM), proyeksi produksi batu bara pada tahun 2020 - 2024 mengalami peningkatan. Di tahun 2020 produksi ditargetkan sebesar 550 juta ton dengan alokasi ekspor 395 juta ton dan domestik 155 juta ton. Di tahun 2021 produksi ditargetkan sebesar 609 juta ton yang terbagi untuk ekspor 441 juta ton dan domestik 168 juta ton. Kemudian pada tahun 2022 sebesar 618 juta ton untuk ekspor 441 juta ton dan domestik 177 juta ton. Selanjutnya di 2023 produksi sebesar 625 juta ton untuk ekspor 441 juta ton dan domestik 184 juta ton. Serta di 2024 produksi ditargetkan sebesar 628 juta ton untuk ekspor 441 juta ton dan domestik 187 juta (Utami, 2020).

Ekspor batu bara Indonesia berkisar antara 70\% sampai $80 \%$ dari total produksi batu bara, sisanya dijual di pasar domestik. Berdasarkan gambaran tersebut, maka penelitian ini mengangkat topik tentang "Analisis Daya Saing Komparatif dan Kompetitif Ekspor Komoditas Batu Bara Tiga Negara Berkembang (Indonesia, Afrika Selatan dan Kolombia)". Penelitian ini menganalisis daya saing ekspor komoditas batu bara Indonesia dibandingkan dengan Afrika Selatan dan Kolombia menggunakan metode Balassa Index atau Revealed Comparative Advantage (RCA) dan Indeks Spesialisasi Perdagangan (ISP). 
Pokok-pokok permasalahan yang akan dibahas dalam penelitian ini adalah: (1) bagaimana tingkat daya saing ekspor batu bara Indonesia dibandingkan dengan Afrika Selatan dan Kolombia? (2) bagaimana tingkat daya saing ekspor batu bara Indonesia dibandingkan dengan kedua negara berkembang tersebut jika dilihat dari indeks spesialisasi perdagangan?

Tujuan dari penelitian ini untuk menganalisis tingkat daya saing ekspor batu bara Indonesia dibandingkan dengan Afrika Selatan dan Kolombia dari sisi keunggulan komparatif atau keunggulan kompetitif dan dari sisi indeks spesialisasi perdagangan, serta membandingkan ekspor dan impor batu bara ketiga negara tersebut dan perkembangan ekspor batu baranya dalam 15 tahun.

\section{TINJAUAN PUSTAKA}

Daya Saing

Daya saing adalah produktivitas atau output yang dihasilkan oleh tenaga kerja. Menurut Institute for Management Development (IMD), daya saing nasional adalah kemampuan suatu negara untuk menciptakan nilai tambah guna menambah kekayaan negara dengan cara mengelola proses dan aset, agresivitas dan daya tarik, proximity dan globality, serta model ekonomi dan sosial (Ristek-BRIN, 2020). Konsep daya saing dan keunggulan komparatif tidak bisa dipisahkan karena terkait erat dalam pelaksanaan perdagangan internasional, serta banyak yang menyebutkan bahwa daya saing artinya sama dengan keunggulan komparatif, namun diantara kedua hal itu tetap terdapat perbedaan. Dalam kondisi tertentu, ekonomi suatu negara bisa kehilangan daya saing dan disisi lain masih bisa mempertahankan keunggulan komparatifnya. Selain itu, suatu negara bisa bersaing tanpa memiliki keunggulan komparatif, meskipun keunggulan komparatif merupakan penentu utama daya saing.

Tabel 2. Perbedaan antara Competitiveness dan Comparative Advantage

\begin{tabular}{|c|c|}
\hline Competitiveness & Comparative Advantage \\
\hline $\begin{array}{l}\text { Daya saing adalah perbandingan antar negara } \\
\text { dalam hal efisiensi produksi. }\end{array}$ & $\begin{array}{l}\text { Keunggulan komparatif adalah perbandingan } \\
\text { produk yang dihasilkan suatu negara dengan } \\
\text { produk yang dihasilkan negara lain. }\end{array}$ \\
\hline $\begin{array}{l}\text { Daya saing suatu produk bergantung pada biaya, } \\
\text { yaitu negara mana yang dapat mengekspor suatu } \\
\text { produknya dengan biaya yang rendah. }\end{array}$ & $\begin{array}{l}\text { Perhitungan keunggulan komparatif dapat } \\
\text { digunakan untuk memprediksi arus perdagangan } \\
\text { dan mengevaluasi sejauh mana alokasi sumber } \\
\text { daya pada suatu industri sudah optimal atau belum. }\end{array}$ \\
\hline $\begin{array}{l}\text { Untuk meningkatkan daya saing dapat dilakukan } \\
\text { dengan mengekspor produk baru atau melakukan } \\
\text { inovasi, seperti menggunakan teknologi yang lebih } \\
\text { maju. }\end{array}$ & $\begin{array}{l}\text { Keunggulan komparatif berfokus pada } \\
\text { perdagangan khusus industri, menjelaskan } \\
\text { mengapa suatu negara mengekspor produk padat } \\
\text { karya (labor-intensive) sementara negara lain } \\
\text { mengekspor produk padat modal (capital- } \\
\text { intensive). }\end{array}$ \\
\hline
\end{tabular}

Sumber: Export Competitiveness Assessment through the Balassa Index (The Case of Armenia) (Sargsyan, 2018).

Keunggulan komparatif adalah inti dari teori perdagangan. Setiap negara memiliki keunggulan komparatif dalam memproduksi suatu produk, seperti produk yang memiliki biaya (opportunity) yang lebih rendah daripada negara pesaingnya (Sargsyan, 2018).

\section{Keunggulan Komparatif}

Perdagangan antar dua negara atau lebih didasarkan pada teori keunggulan mutlak (absolute advantage) dari Adam Smith. Menurut Adam Smith, suatu negara harus melakukan spesialisasi produksi dan mengekspor barang yang memiliki keunggulan mutlak, sedangkan barang yang tidak memiliki keunggulan mutlak lebih baik di impor agar negara tersebut mendapatkan manfaat dari perdagangan internasional (gain from trade). Teori ini didasarkan dengan asumsi hanya tenaga kerja yang digunakan dalam faktor produksi, pertukaran dilakukan secara barter, tidak ada biaya pengiriman serta barang yang diproduksi kedua negara memiliki kualitas yang sama. Terdapat kelemahan dalam teori ini yaitu perdagangan internasional yang menguntungkan tidak akan terjadi jika yang memiliki keunggulan mutlak hanya satu negara untuk kedua jenis produk.

David Ricardo memperkenalkan tentang teori keunggulan komparatif, keunggulan komparatif didasarkan pada nilai tenaga kerja (theory of labor value), artinya untuk memproduksi suatu barang berdasarkan jumlah waktu atau jam kerja menentukan nilai atau harga suatu produk. Jadi, suatu negara akan 
mendapatkan manfaat dari perdagangan internasional jika melakukan spesialisasi produksi dan mengeskpor suatu produk yang jumlah produksinya relatif lebih efisien serta melakukan impor untuk suatu produk yang jumlah produksinya relatif kurang efisien (Hady, 2009).

Teori absolute advantage dan comparative advantage memiliki kelemahan dalam menjelaskan alasan yang mendasari terjadinya perdagangan internasional. Kelemahan teori ini diperbaiki oleh Bamford dan Grant (2012) yang mengajukan teori keunggulan kompetitif. Teori ini berfokus pada biaya produksi aktual dan bagaimana perusahaan terus berupaya untuk mengurangi biaya unit mereka. Hal ini dibuktikan dengan cara perusahaan multinasional yang memindahkan tempat produksinya ke tempat lain dengan biaya produksi lebih rendah untuk mempertahankan daya saingnya. Teori ini menekankan pentingnya kuantitas dan kualitas faktor-faktor produksi. Jenis komoditas ekspor suatu negara tergantung dari sumber daya yang dimiliki.

Contohnya, jika negara tersebut memiliki sumber daya alam berupa minyak, gas alam, emas dan berlian, maka akan cenderung mengekspor komoditas-komoditas tersebut. Seiring berjalannya waktu diperlukan peningkatan kuantitas maupun kualitas tenaga kerja dan modal. Selain itu, pemerintah dapat melakukan kebijakan untuk tidak melakukan spesialisasi yang berlebihan dan memilih memproduksi berbagai macam produk sehingga suatu negara memiliki berbagai produk yang tersedia jika terjadi dislokasi atau gangguan suplai (interruption of supplies). Teori ini jelas berbeda dengan teori absolute advantage dan comparative advantage yang mengharuskan melakukan spesialisasi produksi.

\section{Penelitian Terdahulu}

Penelitian yang dilakukan oleh Mediana Purnamasari, Nuhfil Hanani dan Wen-Chi Huang dengan mengangkat penelitian berjudul Analisis Daya Saing Ekspor Kopi Indonesia di Pasar Dunia, didapatkan hasil dari penelitian tersebut adalah Indonesia belum memiliki keunggulan komparatif dan mengalami penurunan produktifitas kopi diantara negara pengekspor kopi utama lainnya. Selain itu, kompetitor utama Indonesia adalah Vietnam yang juga merupakan eksportir kopi robusta (Purnamasari, Hanani and Huang, 2014).

Penelitian Anton Trianto yang berjudul Analisis Daya Saing Ekspor Komoditi Unggulan Non Migas di Provinsi Sumatera Selatan, didapatkan bahwa yang memiliki daya saing cukup tinggi hanya komoditi karet dan batu bara, sedangkan komoditi unggulan non migas lainnya seperti udang, teh dan kopi belum memiliki daya saing yang baik (Trianto, 2015).

Penelitian Ragimun yang berjudul Analisis Perdagangan Produk Alas Kaki Indonesia-Cina, menunjukkan Indonesia memiliki daya saing yang cukup kuat untuk produk alas kaki dan konsentrasi pasar produk alas kaki tidak seleruhnya terkonsentrasi ke negara Cina serta Indonesia memiliki kecendrungan sebagai negara pengekspor alas kaki ke Cina (Ragimun, 2012).

Dalam penelitian yang dilakukan oleh Isimiati Marfu'ah Rochmat, Darsono dan Erlyna Wida Riptanti dengan judul Analisis Daya Saing Ekspor Komoditas Karet Alam Provinsi Jawa Tengah didapatkan bahwa komoditas karet alam Jawa Tengah memiliki keunggulan komparatif maupun kompetitif dan tren daya saing meningkat (Rochmat, Darsono and Riptanti, 2018).

Penelitian Arpine Sargsyan tentang Analisis Daya Saing Ekspor Menggunakan Balassa Index (Studi Kasus Armenia) menunjukkan bahwa terdapat banyak sektor di Armenia yang berdaya saing lemah atau tidak memiliki keunggulan komparatif dalam ekspornya. Hal ini disebabkan oleh beberapa faktor seperti eksportir memiliki masalah yang sama, eksportir mengalami masalah internal, masalah yang terjadi dalam pasar ekspor dan terkait dengan kebijakan pemerintah (Sargsyan, 2018).

\section{METODE PENELITIAN}

Jenis penelitian yang digunakan adalah kuantitatif dan deskriptif, untuk menganalisis daya saing ekspor komoditas batu bara Indonesia dibandingkan dengan Afrika Selatan dan Kolombia dilakukan dengan cara mengukur variabel-variabel yang terkait berdasarkan data ekspor-impor Indonesia, Afrika Selatan dan Kolombia. Hasil analisis tersebut kemudian akan diinterpretasikan dan dideskripsikan untuk diambil kesimpulannya. Dalam penelitian ini, jenis data yang digunakan adalah sekunder yang didapatkan dari International Trade Centre (ITC) dalam Peta Dagang Indonesia dan unit analisis yang digunakan adalah nilai ekspor dan impor batu bara serta nilai ekspor bahan bakar mineral dalam US\$ dari tiga negara berkembang yaitu Indonesia, Afrika Selatan dan Kolombia.

Teknik Pengumpulan Data

Teknik pengumpulan data yang digunakan dalam penelitian ini adalah dokumentasi berupa data ekspor dan impor batu bara serta data ekspor bahan bakar mineral tiga negara berkembang yaitu Indonesia, Afrika Selatan dan Kolombia yang didapatkan dari International Trade Centre (ITC). 
Teknik Analisis Data

Revealed Comparative Advantage (RCA) atau Balassa Index

Balassa Index atau yang lebih dikenal dengan Revealed Comparative Advantage (RCA) adalah metode analisis yang digunakan untuk menghitung daya saing komoditas suatu negara. Menurut Balassa diperlukan untuk membandingkan rasio ekspor (share of exports) dengan total ekspor suatu negara untuk menentukan apakah negara tersebut memiliki daya saing yang kuat dalam industri atau komoditas yang di ekspor (Sargsyan, 2018). Adapun cara menghitung RCA adalah sebagai berikut :

Hasil:

$$
B I_{j}^{A}=\frac{\text { Rasio dari ekspor batu bara di negara Indonesia }}{\text { Rasio dari ekspor batu bara di negara lain }}
$$

$B I_{j}^{A}>1$, berarti negara tersebut memiliki keunggulan komparatif terhadap ekspor komoditas batu bara.

$B I_{j}^{A}<1$, berarti negara tersebut tidak memiliki keunggulan komparatif terhadap ekspor komoditas batu bara.

Dimana $B I_{j}^{A}$ adalah nilai RCA komoditas batu bara, sedangkan rasio ekspor batu bara didapatkan dari total ekspor batu bara negara A dibagi dengan total ekspor bahan bakar mineral negara A. Metode ini dapat diterapkan untuk semua negara dan semua komoditas. Indeks ini menentukan seberapa banyak ekspor suatu negara.

Indeks Spesialisasi Perdagangan (ISP) atau Trade Specialization Index (TSI)

Dalam suatu komoditas untuk mengetahui apakah suatu negara cenderung menjadi negara pengekspor atau pengimpor diperlukan metode perhitungan Indeks Spesialisasi Perdagangan (ISP) (Kemendag.go.id, 2008). Metode perhitungan ini juga dapat digunakan untuk mengidentifikasi tingkat pertumbuhan suatu komoditas dalam perdagangan yang terbagi ke dalam lima tahap, yaitu tahap pengenalan, tahap subtitusi impor, tahap pertumbuhan, tahap kematangan dan tahap kembali mengimpor. Adapun cara menghitung ISP adalah sebagai berikut :

$$
I S P=\frac{X_{i a}-M_{i a}}{X_{i a}+M_{i a}}
$$

Hasil:

Jika nilai ISP positif (>0 sampai dengan 1), maka negara tersebut cenderung menjadi negara pengeskpor komoditas batu bara dan memiliki daya saing yang kuat.

Jika nilai ISP negatif ( $<0$ sampai dengan -1$)$, maka negara tersebut cenderung menjadi negara pengimpor komoditas batu bara dan memiliki daya saing yang lemah.

Di mana $\mathrm{X}$ dan $\mathrm{M}$ adalah ekspor dan impor, serta i dan a adalah komoditas batu bara negara Indonesia, Afrika Selatan dan Kolombia.

\section{HASIL DAN PEMBAHASAN}

Analisis Revealed Comparative Advantage (RCA) atau Balassa Index

Untuk mengetahui keunggulan komparatif ekspor komoditas batu bara Indonesia dibandingkan dengan Afrika Selatan dan Kolombia, maka peneliti akan mengolah data menggunakan metode analisis Balassa Index atau Revealed Comparative Advantage (RCA). Tujuannya untuk mengetahui tingkat daya saing komparatif ekspor batu bara Indonesia dibandingkan dengan Afrika Selatan dan Kolombia.

Dari hasil analisis perhitungan menggunakan Balassa Index atau Revealed Comparative Advantage (RCA), didapatkan nilai rata-rata RCA negara Indonesia dibandingkan dengan Afrika Selatan sebesar 0,59, yang artinya nilai RCA $<1$, maka tingkat daya saing ekspor komoditas batu bara Indonesia berdaya saing lemah atau tidak memiliki keunggulan komparatif jika dibandingkan dengan Afrika Selatan. Nilai rata-rata RCA Indonesia dibandingkan Kolombia selama lima belas tahun sebesar 1,43, yang artinya nilai RCA > 1, maka tingkat daya saing ekspor komoditas batu bara Indonesia berdaya saing kuat atau memiliki keunggulan komparatif jika dibandingkan dengan Kolombia.

Hasil perhitungan nilai daya saing Indonesia dibandingkan dengan kedua negara berkembang tersebut pada tahun 2004 - 2018 dengan menggunakan metode RCA dapat dilihat pada tabel dibawah ini : 
Tabel 3. Nilai RCA Ekspor Batu Bara Indonesia dibandingkan dengan Afrika Selatan Tahun 2004 - 2018

\begin{tabular}{ccc}
\hline Tahun & Nilai RCA & Kategori \\
\hline 2004 & 0,23 & \\
2005 & 0,27 & \\
2006 & 0,35 & \\
2007 & 0,46 & \\
2008 & 0,40 & \\
2009 & 0,60 & \\
2010 & 0,62 & Tidak memiliki keunggulan komparatif \\
2011 & 0,56 & \\
2012 & 0,64 & \\
2013 & 0,69 & \\
2014 & 0,68 & \\
2015 & 0,80 & \\
2016 & 0,85 & \\
2017 & 0,89 & \\
2018 & 0,79 & \\
\hline Rata-rata & $\mathbf{0 , 5 9}$ & Tidak memiliki keunggulan komparatif \\
\hline & Sumber: International Trade Centre (data diolah)
\end{tabular}

Tabel 4. Nilai RCA Ekspor Batu Bara Indonesia dibandingkan dengan Kolombia Tahun $2004-2018$

\begin{tabular}{ccc}
\hline Tahun & Nilai RCA & Kategori \\
\hline 2004 & 0,52 & \\
2005 & 0,63 & Memiliki keunggulan komparatif \\
2006 & 0,74 & \\
2007 & 0,75 & \\
2008 & 0,99 & \\
2009 & 1,26 & \\
2010 & 1,59 & \\
2011 & 1,72 & Memiliki keunggulan komparatif \\
2012 & 2,08 & \\
2013 & 2,49 & \\
2014 & 2,04 & \\
2015 & 1,88 & \\
2016 & 1,56 & \\
2017 & 1,45 & Memiliki keunggulan komparatif \\
2018 & 1,80 & $\mathbf{1 , 4 3}$ \\
\hline Rata-rata & Sumber: International Trade Centre (data diolah)
\end{tabular}

Dari segi kualitas, ekspor komoditas batu bara Indonesia, Afrika Selatan dan Kolombia tidak bisa dibandingkan karena ketiga negara tersebut memiliki kualitas batu bara yang berbeda. Indonesia memiliki sumber daya batu bara yang melimpah dengan kualitas rendah dan menengah.Terdapat $60 \%$ dari cadangan batu bara total Indonesia terdiri dari batu bara kualitas rendah yang lebih murah (sub-bituminous), 
sedangkan Afrika Selatan memiliki 96\% cadangan batu bara bitumen, 2\% metalurgi, dan 2\% antrasit dan Kolombia memiliki $94 \%$ batu bara dengan kualitas yang sangat baik dan tergolong keras, dengan kapasitas pembangkit panas yang tinggi. Hal ini mengakibatkan harga jual batu bara ketiga negara tersebut berbeda karena memiliki kualitas yang berbeda pula.

Selain kualitas dan harga terdapat faktor lain yang dapat mempengaruhi daya saing seperti meningkatkan kuantitas dan kualitas faktor-faktor produksi, permintaan konsumen, biaya transpor, letak geografis dan hambatan perdagangan (trade barrier). Dari sisi kuantitas, ekspor batu bara Indonesia jauh lebih banyak daripada Afrika Selatan, akan tetapi berdasarkan hasil analisis data menggunakan metode RCA dinyatakan bahwa tingkat daya saing komoditas ekspor batu bara Indonesia tidak memiliki keunggulan komparatif dibandingkan negara Afrika Selatan. Hal ini dikarenakan pangsa pasar Afrika Selatan bergeser arah dari wilayah Eropa ke Asia yang menjadikan Afrika Selatan sebagai negara kompetitor Indonesia di pasar Asia Selatan, khususnya di India dan di pasar Asia Timur, khususnya Cina.

Pada tahun 2016 impor batu bara India menurun dikarenakan negara Asia Selatan tersebut beralih ke bahan bakar berkualitas lebih tinggi, mengakibatkan impor batu bara India dari Indonesia menurun hampir $20 \%$ dari 46,9 juta ton pada tahun 2015 menjadi 36,72 juta ton pada tahun 2016, sedangkan impor batu bara India dari Afrika Selatan sebesar 16,58 juta ton pada tahun 2016, naik hampir 26\% dibandingkan sebelumnya. Afrika Selatan memiliki peluang untuk merebut sebagian pangsa pasar batu bara milik eksportir Indonesia dengan berkurangnya ekspor batu bara Indonesia ke India (IwanQH, 2016).

Pemerintah India bertujuan untuk menghentikan impor batu bara dalam beberapa tahun ke depan karena telah terjadi kelebihan produksi atau kelebihan persediaan batu bara dalam negeri. Selain itu, importir batu bara termal India memilih untuk membayar biaya pengiriman yang lebih mahal dengan kualitas batu bara yang lebih baik daripada biaya pengiriman yang murah dengan kualitas batu bara yang rendah, ini menunjukkan adanya inovasi atau peningkatan dalam faktor produksi dengan kemajuan teknologi yang lebih baik untuk pembangkit listrik di India. Meningkatnya ekspor batu bara Afrika Selatan ke India juga dipengaruhi oleh berkurangnya biaya transpor (freight) dikarenakan membaiknya infrastruktur transportasi ke pelabuhan batu bara. Impor batu bara India dari Kolombia juga mengalami kenaikan dari 46.000 pada tahun 2015 menjadi 981.000 ton pada tahun 2016 (Russell, 2016). Dari gambaran tersebut dapat diambil kesimpulan Indonesia berdaya saing lemah atau tidak memiliki daya saing komparatif jika dibandingkan dengan negara Afrika Selatan.

Berdasarkan hasil analisis data menggunakan metode RCA, Indonesia ternyata tidak memiliki keunggulan komparatif dibandingkan Afrika Selatan. Namun disisi lain, berdasarkan tujuan negara ekspor yaitu Cina, komoditas batu bara Indonesia memiliki keunggulan dibandingkan Afrika Selatan karena memiliki peluang yang besar untuk melakukan ekspor ke Cina. Walaupun impor batu bara Cina dari Afrika Selatan naik dari nol menjadi 17\% pada tahun 2009 dan 2011, namun pada tahun 2014 Cina mengurangi impor batu baranya secara umum termasuk Indonesia dan Afrika Selatan. Cina memberlakukan kembali kebijakan tarif impor sebesar 3\% hingga 6\% untuk semua jenis batu bara. Kebijakan ini dilakukan untuk melindungi perusahaan batu bara domestik Cina dan mengurangi polusi di Cina akibat penggunaan batu bara. Kebijakan ini mempengaruhi ekspor batu bara Afrika Selatan ke Cina, Afrika Selatan tidak lagi diizinkan mengekspor batu bara ke Cina semenjak Maret 2014 dikarenakan kebijakan ini. Hal ini menguntungkan bagi Indonesia dikarenakan Indonesia merupakan anggota blok perdagangan ASEAN, yang memiliki perjanjian perdagangan bebas dengan Cina mengakibatkan Indonesia kebal terhadap kebijakan tarif ini (City-press, 2014), sedangkan batu bara Kolombia hanya sebagai opsi cadangan ketika harga batu bara regional melonjak dikarenakan waktu pengiriman yang lama jika dibandingkan dengan Indonesia (Mullen, 2021). Berdasarkan fakta itulah yang menjadikan komoditas batu bara Indonesia memiliki keunggulan dibandingkan Afrika Selatan.

Berdasarkan hasil analisis data menggunakan metode RCA dinyatakan bahwa tingkat daya saing komoditas ekspor batu bara Indonesia berdaya saing kuat atau memiliki keunggulan komparatif jika dibandingkan dengan negara Kolombia. Hal ini dikarenakan pangsa pasar batu bara kawasan Pasifik didominasi oleh Indonesia yang dapat memasok batu bara dengan biaya yang lebih rendah daripada Kolombia. Indonesia diuntungkan karena kedekatannya dengan pasar di Cina, Korea, Jepang serta negaranegara lainnya di Asia Tenggara.

Pembangkit listrik berbahan bakar batu bara di negara-negara di Asia Tenggara dirancang untuk batu bara dengan kualitas rendah dari Indonesia yang dapat mengirimkan batu bara dengan biaya pengiriman yang rendah karena jarak yang dekat serta akses transportasi laut yang mudah. Hal ini menyebabkan batu bara dari Kolombia sulit untuk memasuki pasar di Asia Tenggara. Sejak akhir 2000-an, Cina dan India adalah importir terbesar batu bara di dunia. Indonesia, Australia dan Rusia adalah pengekspor batu bara uap terbesar di dunia, diikuti oleh Kolombia dan Afrika Selatan (Oei and Mendelevitch, 2016). 
Pada tahun 2009 hingga 2013 terjadi pertumbuhan ekspor batu bara Indonesia yang tajam dikarenakan lonjakan permintaan batu bara dari Cina dan India. Perubahan ini juga didorong oleh diterapkannya Undang-Undang Pertambangan Mineral dan Batu Bara pada tahun 2009, yang memberikan kontrol lebih besar kepada pemerintah pusat atas izin di sektor pertambangan. Terlepas dari perubahan tersebut, Indonesia mampu meningkatkan $68 \%$ produksi batu bara selama periode tersebut, dari 291 juta ton pada tahun 2009 menjadi 490 juta ton pada tahun 2013. Sebagian besar batu bara tersebut di ekspor ke Cina dan India. Kedua negara tersebut menyerap hampir $90 \%$ ekspor batu bara selama periode tersebut, hanya sekitar 4\% untuk konsumsi domestik. Dalam waktu yang relatif yang singkat, industri batu bara Indonesia menjadi sangat bergantung pada pasar ekspor dengan sekitar $80 \%$ produksi batu bara yang diekspor. Hal ini dikarenakan ketersediaan tambang murah yang dekat dengan pelabuhan serta lokasi geografis Indonesia yang menguntungkan untuk melayani pusat permintaan batu bara dalam sepuluh tahun terakhir, yaitu Cina dan India. Berbeda dengan batu bara Kolombia yang jarang dijual ke Cina dikarenakan jarak pengiriman yang jauh.

Pada periode 2014 hingga sekarang, produksi dan ekspor batu bara dikontrol ketat oleh pemerintah pusat. Pemerintah menerapkan peraturan yang lebih ketat terkait penambangan dan ekspor batu bara. Hal ini dilakukan untuk menghentikan penambangan dan ekspor batu bara ilegal di Indonesia dikarenakan Indonesia kelebihan supply batu bara pada periode sebelumnya. Oleh karena itu, pemerintah membuat Rencana Pembangunan Jangka Menengah Nasioal (RPJMN) tahun 2015 - 2019, pemerintah menetapkan rencana produksi batu bara yang ditargetkan dari 425 juta ton pada tahun 2015 menjadi 400 juta ton pada tahun 2019 (Cornot-Gandolphe, 2017). Pada tahun 2016 impor batu bara India dari Kolombia mengalami kenaikan dari 46.000 menjadi 981.000 ton dibandingkan dengan tahun 2015, namun masih lebih sedikit dibandingkan dengan Indonesia. Indonesia memainkan peran kunci sebagai negara pemasok batu bara untuk memenuhi permintaan terhadap batu bara (Russell, 2016). Sebab-sebab itulah yang menjadikan komoditas batu bara Indonesia berdaya saing kuat atau memiliki keunggulan komparatif jika dibandingkan dengan Kolombia.

Analisis Indeks Spesialisasi Perdagangan (ISP) atau Trade Specialization Index (TSI)

Indeks Spesialisasi Perdagangan (ISP) digunakan untuk mengukur tingkat daya saing dengan tujuan untuk mengetahui apakah negara Indonesia, Afrika Selatan dan Kolombia cenderung menjadi negara pengekspor atau pengimpor dalam komoditas batu bara. Dari hasil perhitungan selama lima belas tahun yaitu 2004 - 2018 didapatkan rata-rata nilai ISP untuk negara Indonesia sebesar 0,98 sedangkan untuk Afrika Selatan sebesar 0,90 dan untuk Kolombia sebesar 1,00. Nilai rata-rata ISP ketiga negara tersebut adalah positif (>0 sampai dengan 1), sehingga cenderung menjadi negara pengekspor batu bara (penawaran domestik lebih besar daripada permintaan domestik) serta memiliki daya saing yang kuat. Selain menjadi negara eksportir batu bara di dunia, ketiga negara tersebut juga menjadi negara importir batu bara namun jumlah impornya tidak terlalu besar. Hasil dari perhitungan dengan menggunakan metode ISP dapat dilihat pada tabel berikut :

Tabel 5. Nilai ISP Ekspor Batu Bara Indonesia, Afrika Selatan dan Kolombia Tahun $2004-2018$

\begin{tabular}{cccc}
\hline Tahun & ISP Indonesia & ISP Afrika Selatan & ISP Kolombia \\
\hline 2004 & 0,99 & 0,92 & 1,00 \\
2005 & 0,99 & 0,90 & 1,00 \\
2006 & 1,00 & 0,85 & 1,00 \\
2007 & 1,00 & 0,89 & 1,00 \\
2008 & 1,00 & 0,81 & 1,00 \\
2009 & 1,00 & 0,92 & 1,00 \\
2010 & 1,00 & 0,97 & 1,00 \\
2011 & 1,00 & 0,93 & 1,00 \\
2012 & 1,00 & 0,96 & 1,00 \\
2013 & 0,99 & 0,90 & 1,00 \\
2014 & 0,97 & 0,90 & 1,00 \\
\hline
\end{tabular}




\begin{tabular}{cccc} 
lanjutan & \multicolumn{1}{c}{} \\
\hline 2015 & 0,96 & 0,91 & 1,00 \\
2016 & 0,95 & 0,90 & 1,00 \\
2017 & 0,93 & 0,85 & 1,00 \\
2018 & 0,92 & 0,84 & 1,00 \\
\hline Rata-rata & $\mathbf{0 , 9 8}$ & $\mathbf{0 , 9 0}$ \\
\hline & Sumber: International Trade Centre (data diolah)
\end{tabular}

Metode perhitungan ini juga dapat digunakan untuk mengidentifikasi tingkat pertumbuhan suatu komoditas batu bara dalam perdagangan.

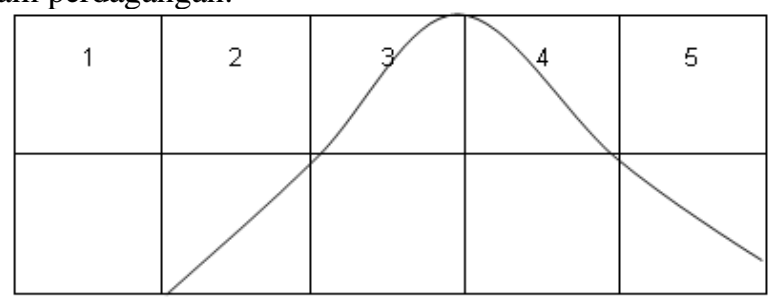

Gambar 1. Kurva ISP sesuai Teori Siklus Produk

Hasil perhitungan ketiga negara berkembang tersebut berada pada kisaran 0,81 sampai 1,00 yang merupakan tahap kematangan. Pada tahap ini produk berada pada tahap standardisasi terkait teknologi yang digunakan serta negara Indonesia, Afrika Selatan dan Kolombia merupakan negara net exporter. Berdasarkan kurva pada Gambar 1 dapat diambil kesimpulan bahwa Indonesia, Afrika Selatan dan Kolombia berada pada tahap ke empat yaitu tahap kematangan.

\section{Keterbatasan Penelitian}

Peneliti menyadari terdapat banyak kekurangan dan keterbatasan dalam penelitian ini, terutama tentang informasi mengenai alasan Afrika Selatan dan Kolombia melakukan impor batu bara padahal kedua negara tersebut merupakan salah satu negara terbesar eksportir batu bara. Namun peneliti berusaha menggambarkan alasan kedua negara tersebut melakukan impor dengan asumsi bahwa negara Afrika Selatan dan Kolombia merupakan negara berkembang sama halnya dengan Indonesia. Penelitian ini juga tidak menjelaskan daya saing batu bara yang dipengaruhi oleh nilai tukar dan harga minyak dunia.

Implikasi Penelitian

Berdasarkan teori, kemampuan suatu negara untuk mencapai pertumbuhan ekonomi yang tinggi dan berkelanjutan dengan cara menciptakan nilai tambah dalam suatu produk disebut dengan daya saing. Konsep daya saing dan keunggulan komparatif tidak bisa dipisahkan karena terkait erat dalam pelaksanaan perdagangan internasional, karena hal ini banyak yang menyebutkan daya saing sama dengan keunggulan komparatif, namun tetap terdapat perbedaan diantara keduanya. Dalam kondisi tertentu, perekonomian suatu negara bisa mengalami kehilangan daya saing, tetapi disisi lain masih bisa mempertahankan keunggulan komparatifnya. Selain itu, suatu negara bisa bersaing tanpa memiliki keunggulan komparatif (Sargsyan, 2018).

Dari hasil penelitian ini dapat diketahui bahwa Indonesia berdaya saing lemah atau tidak memiliki keunggulan komparatif jika dibandingkan dengan negara Afrika Selatan. Akan tetapi, Indonesia berdaya saing kuat atau memiliki keunggulan komparatif jika dibandingkan dengan negara Kolombia. Disisi lain Indonesia, Afrika Selatan dan Kolombia juga memiliki daya saing yang kuat dan cenderung dominan menjadi negara pengekspor batu bara karena jumlah produksi batu bara dalam negeri lebih banyak daripada jumlah kebutuhan batu bara dalam negeri (penawaran domestik lebih besar daripada permintaan domestik).

Pada tahun 2009 pemerintah Indonesia menerapkan Undang-Undang Pertambangan Mineral dan Batu Bara (Minerba), yang membuat pemerintah pusat memiliki kontrol lebih besar atas izin di sektor pertambangan. Undang-undang ini dimaksudkan untuk meningkatkan investasi asing dalam sektor pertambangan dan memperjelas tanggung jawab antara pemerintah pusat, provinsi, dan kabupaten untuk mengeluarkan izin pertambangan di wilayah mereka. Setelah penerapan undang-undang tersebut, jumlah izin pertambangan yang dikeluarkan oleh pemerintah meningkat tajam. Hal ini menyebabkan peningkatan produksi dan ekspor batu bara yang tidak terkendali selama periode 2009 - 2013, termasuk meningkatnya penambangan dan ekspor ilegal. Pada tahun 2010, pemerintah mengeluarkan peraturan yang mewajibkan pemegang Izin Usaha Pertambangan (IUP) untuk meningkatkan nilai batu bara dengan cara melakukan 
pengolahan di dalam negeri. Undang-undang ini kemudian direvisi pada tahun 2014, menjelaskan tentang "pengolahan" batu bara mencakup kegiatan seperti penremukan batu bara, pencucian batu bara, pemekatan dan atau penghilangan batuan/mineral pengotor atau senyawa belerang dari batu bara tanpa mengubah sifat kimianya. Selain itu, sejak Agustus 2015, pemerintah telah mengenakan pajak ekspor batu bara 1,5\% kepada pemegang Izin Usaha Pertambangan (IUP) dan eksportir maupun importir batu bara (CornotGandolphe, 2017).

Merujuk pada skenario International Energy Agency's (IEA) Net Zero Emission di World Energy Outlook (WEO) 2020, permintaan batu bara untuk pembangkit listrik akan turun 66\% di kurun waktu 2019 - 2030. Kebijakan ini dilakukan untuk mencapai target bebas karbon atau emisi nol bersih (net zero emissions) pada 2050. IEA telah menetapkan lebih dari 400 titik penting (milestone) untuk mencapai emisi nol tersebut, termasuk tidak ada lagi investasi untuk proyek bahan bakar fosil baru mulai sekarang, dan juga tidak ada lagi investasi untuk Pembangkit Listrik Tenaga Uap (PLTU) yang tidak memiliki teknologi carbon capture. Pemanfaatan Energi Baru Terbarukan (EBT) secara besar-besaran sangat diperlukan. Pembangkit listrik di tahun 2050 sebesar 90\%-nya harus berasal dari Energi Baru Terbarukan (EBT) dan sisanya dari nuklir.

Berdasarkan hasil analisis penelitian ini secara keseluruhan menunjukkan nilai ekspor mentah batu bara Indonesia masih sangat dominan dan masih menjadi ekspor andalan hingga saat ini. Hal ini menunjukkan ketidakmampuan pemerintah khususnya Kementerian Energi dan Sumber Daya Mineral (ESDM) dalam mengendalikan tingkat produksi batu bara nasional. Pemerintah Indonesia membuat Rencana Pembangunan Jangka Menengah Nasioal (RPJMN) tahun 2015 - 2019, pemerintah menetapkan rencana target produksi batu bara dari 425 juta ton pada tahun 2015 menjadi 400 juta ton pada tahun 2019. Target produksi batu bara tahunan yang ditetapkan dalam RPJMN 2015 - 2019 telah terlampaui pada tahun 2015 volume ekspor batu bara tercatat sebanyak 367 juta ton dengan nilai sebesar US\$ 16 miliar. Pada tahun 2016, volume ekspor batu bara naik menjadi 370 juta ton dengan nilai US\$ 15 miliar (CornotGandolphe, 2017). Pada tahun 2017, volume ekspor batu bara ini bertambah lagi menjadi 389 juta ton dengan nilai US\$ 20 miliar serta diikuti oleh tren kenaikan harga. Mulai tahun 2021, pemerintah menargetkan volume ekspor batu bara tidak melampaui batasan yang ada dalam Rencana Umum Energi Nasional (RUEN), dengan target volume ekspor batu bara tetap sebesar 441 juta ton hingga tahun 2024 (Mulyana, 2020).

Ekspor batu bara akan dilakukan dengan syarat setelah terpenuhinya kebutuhan dalam negeri, mempertimbangkan perkembangan harga batu bara dan permintaan batu bara global. Pemerintah memprioritaskan pemenuhan kebutuhan batu bara untuk keperluan domestik seperti Pembangkit Listrik Tenaga Uap (PLTU) berdasarkan draf Rencana Usaha Penyediaan Tenaga Listrik (RUPTL) PLN 20212030 (Umah, 2021). Dalam jangka pendek, Indonesia masih bergantung pada ekspor batu bara. Namun, dalam jangka menengah dan panjang, pemerintah akan mengontrol produksi batu bara untuk memastikan sumber daya yang cukup untuk pembangkit listrik tenaga batu bara baru, sehingga jumlah ekspor batu bara akan berkurang secara signifikan pada tahun 2025 (Cornot-Gandolphe, 2017). Dengan kebijakan akan dihentikannya ekspor batu bara mentah dapat mendorong pengembangan industri turunan batu bara atau hilirisasi (mengubah bahan baku mentah menjadi barang jadi), sehingga akan menambah nilai daya saing ekspor batu bara Indonesia dari segi harga dan kualitas dan menyesuaikan dengan kebutuhan batu bara di masa depan. Akibat kebijakan dunia untuk mencapai target bebas karbon atau emisi nol bersih (net zero emissions) pada 2050 yang akan berdampak dengan berkurangnya penggunaan batu bara di Pembangkit Listrik Tenaga Uap (PLTU), maka harus segara dilakukan hilirisasi batu bara.

Indonesia telah menandatangani Paris Agreement pada 2015 lalu. Perjanjian tersebut memiliki misi untuk menurunkan emisi gas rumah kaca, termasuk dengan pengurangan batu bara. Pada tahun 2050, Cina juga akan menerapkan kebijakan untuk tidak menggunakan Penyediaan Tenaga Listrik (PLTU). Saat ini, perseroan tengah bekerja sama dengan konsorsium PT Pertamina (Persero) dan Air Products, perusahaan asal Amerika Serikat, untuk melakukan proyek gasifikasi batu bara menjadi dimethyl ether (DME). Pada tahun 2020, Presiden Joko Widodo memasukkan proyek DME ke dalam salah satu Proyek Strategi Nasional (PSN) yang ditetapkan pada akhir tahun 2020 untuk mendukung proyek ini. Pemerintah juga memberikan sejumlah insentif seperti royalti batu bara $0 \%$ untuk proyek gasifikasi, keringanan pajak berupa tax holiday dan lainnya untuk mendorong produsen batu bara agar segera melakukan hilirisasi batu bara (Hastuti, 2021). Kebijakan tersebut akan menambah nilai daya saing ekspor batu bara Indonesia dan dapat bersaing di pangsa pasar batu bara di masa depan. 


\section{KESIMPULAN DAN SARAN}

Kesimpulan

Kesimpulan dari penelitian ini yang pertama adalah dengan menggunakan metode analisis Balassa Index atau Revealed Comparative Advantage (RCA), didapatkan nilai rata-rata RCA negara Indonesia dibandingkan dengan Afrika Selatan adalah RCA $<1$, artinya tingkat daya saing ekspor komoditas batu bara Indonesia berdaya saing lemah atau tidak memiliki keunggulan komparatif jika dibandingkan dengan Afrika Selatan, sedangkan nilai rata-rata RCA Indonesia dibandingkan Kolombia selama lima belas tahun adalah RCA > 1, yang artinya ekspor komoditas batu bara Indonesia berdaya saing kuat atau memiliki keunggulan komparatif jika dibandingkan dengan Kolombia.

Kedua, berdasarkan hasil analisis data menggunakan Indeks Spesialisasi Perdagangan (ISP), didapatkan nilai rata-rata ISP untuk negara Indonesia, Afrika Selatan dan Kolombia hasilnya positif (>0 sampai dengan 1), ketiga negara tersebut dikategorikan cenderung menjadi negara pengekspor batu bara (penawaran domestik lebih besar daripada permintaan domestik) serta memiliki daya saing yang kuat.

Saran

Saran yang dikemukakan dalam penelitian ini yaitu yang pertama, batu bara Indonesia didominasi oleh jenis batu bara berkualitas menengah dan rendah, selain itu permintaan batu bara di pasar dunia sekarang lebih selektif. Negara-negara pengimpor batu bara memilih batu bara dengan kualitas yang lebih baik dan emisi CO2 per kWhnya rendah sesuai dengan skenario International Energy Agency's (IEA) untuk mencapai target bebas karbon atau emisi nol bersih (Net Zero Emission) pada tahun 2050, sehingga perlu dilakukan pengembangan industri turunan batu bara atau hilirisasi (mengubah bahan baku mentah menjadi barang jadi) menggunakan penerapan teknologi yang ramah lingkungan terhadap industri batu bara guna meningkatkan nilai jual batu bara dan mengurangi emisi $\mathrm{CO} 2$ yang dihasilkan. Hal ini dilakukan untuk meningkatkan daya saing di pasar internasional, baik dari segi harga maupun kualitas.

Kedua, untuk negara-negara yang menjadikan ekspor batu bara sebagai salah satu ekspor utamanya, khususnya Indonesia, Afrika Selatan dan Kolombia agar dapat beralih dengan memprioritaskan pengembangan energi non-fosil, sebagai upaya mengganti energi tinggi karbon sebagai Energi Baru Terbarukan (EBT) karena batu bara merupakan sumber daya alam yang terbatas, tidak dapat diandalkan secara berkelanjutan karena suatu saat cadangan batu bara akan habis sehingga dapat memukul perekonomian ketiga negara tersebut.

Ketiga, diharapkan untuk Indonesia, Afrika Selatan dan Kolombia untuk memprioritaskan pemenuhan permintaan batu bara dalam negeri dibanding luar negeri, sesuai dengan teori net of surplus, dimana ekspor dilakukan apabila permintaan domestik sudah terpenuhi dan ada kelebihan atas barang tersebut di pasar domestik.

Keempat, diharapkan untuk mengembangkan penelitian terkait perdagangan internasional khususnya ekspor untuk komoditas lainnya seperti kelapa sawit, rotan dan sebagainya bagi para peneliti selanjutnya.

\section{DAFTAR PUSTAKA}

APBI-ICMA (2021) Indonesian Coal Mining Association (APBI) \& Ministry of Energy and Mineral Resources, Asosiasi Pertambangan Batubara Indonesia. Available at: http://www.apbiicma.org/indonesian-coal-data.

Bamford, C. and Grant, S. (2012) Economics. Cambridge University Press.

City-press (2014) Sun Sets on SA's Coal Exports to China, news24. Available at: https://www.news24.com/news24/Archives/City-Press/Sun-sets-on-SAs-coal-exports-to-China20150429 (Accessed: 10 June 2021).

Cornot-Gandolphe, S. (2017) 'Indonesia's Electricity Demand and the Coal Sector: Export or Meet Domestic Demand?', The Oxford Institute for Energy Studies Paper CL 5. doi: https://doi.org/10.26889/9781784670795.

Hady, H. (2009) Ekonomi Internasional Teori dan Kebijakan Perdagangan Internasional. Bogor: Ghalia Indonesia.

Hastuti, R. K. (2021) Terungkap! Ini Alasan PTBA Genjot Hilirisasi Batu Bara, CNBC Indonesia. Available at: https://www.cnbcindonesia.com/news/20210324154310-4-232562/terungkap-inialasan-ptba-genjot-hilirisasi-batu-bara (Accessed: 11 June 2021).

Indonesia-Investments (2018) Batubara, Van der Schaar Investments B.V. Available at: 
https://www.indonesia-investments.com/ (Accessed: 5 November 2020).

IwanQH (2016) Afrika Selatan Tingkatkan Ekspor Batu Bara ke India, tambang.co.id. Available at: https://www.tambang.co.id/afrika-selatan-tingkatkan-ekspor-batu-bara-ke-india-9908/ (Accessed: 10 June 2021).

Kemendag.go.id (2008) Indeks Spesialisasi Perdagangan (ISP), Kemendag.go.id. Available at: https://www.kemendag.go.id/addon/isp/.

Mullen, A. (2021) China Coal: Why is it so Important to the Economy?, scmp.com. Available at: https://www.scmp.com/economy/china-economy/article/3121426/china-coal-why-it-so-importanteconomy (Accessed: 10 June 2021).

Mulyana, R. N. (2020) Digertak Jokowi, Ekspor Batubara akan Dihentikan Sebelum Tahun 2046?, Kontan.co.id. Available at: https://industri.kontan.co.id/news/digertak-jokowi-ekspor-batubaraakan-dihentikan-sebelum-tahun-2046?page $=$ all.

Oei, P.-Y. and Mendelevitch, R. (2016) 'Perspectives on Colombian Coal Exports on the International Steam Coal Market until 2030', Rosa-Luxemburg-Stiftung, pp. 1-47. Available at: https://www.researchgate.net/publication/311953552_Perspectives_on_Colombian_Coal_Exports_ on_the_International_Steam_Coal_Market_until_2030.

Purnamasari, M., Hanani, N. and Huang, W.-C. (2014) 'Analisis Daya Saing Ekspor Kopi Indonesia di Pasar Dunia', AGRISE, XIV(1). Available at: https://agrise.ub.ac.id/index.php/agrise/article/view/117.

Ragimun (2012) 'Analisis Perdagangan Produk Alas Kaki Indonesia - China', Kajian Ekonomi dan Keuangan, 16(2012), pp. 1-21. Available at: https://fiskal.kemenkeu.go.id/ejournal/index.php/kek/article/view/39.

Ristek-BRIN (2020) 'Panduan Indeks Daya Saing Daerah 2020', Kementerian Riset dan Teknologi, pp. 1122. Available at: https://indeks.inovasi.ristekbrin.go.id/upload/cms/panduan_1_1591346017.pdf.

Rochmat, I. M., Darsono, D. and Riptanti, E. W. (2018) 'Analisis Daya Saing Ekspor Komoditas Karet Alam Provinsi Jawa Tengah', Caraka Tani: Journal of Sustainable Agriculture, 32(2), pp. 95-100. Available at: https://jurnal.uns.ac.id/carakatani/article/view/13670.

Russell, C. (2016) India's Changing Coal Imports Show Quality Over Quantity: Russell, REUTERS. Available at: https://www.reuters.com/article/us-column-russell-coal-india-idUSKCN0Z70GI (Accessed: 8 June 2021).

Sargsyan, A. (2018) 'Export Competitiveness Assessment through the Balassa Index (The Case of Armenia)', Preprints. doi: 10.20944/preprints201806.0253.v1.

Trianto, A. (2015) 'Analisis Daya Saing Ekspor Komoditi Unggulan Non Migas di Provinsi Sumatera Selatan', Jurnal Akuntansi, 11(1), pp. 1-29. Available at: https://fe.ummetro.ac.id/ejournal/index.php/JA/article/view/9.

Umah, A. (2021) 2021, Batu Bara untuk PLTU Diperkirakan Naik ke 113 Juta Ton, CNBC Indonesia. Available at: https://www.cnbcindonesia.com/news/20210322135706-4-231903/2021-batu-barauntuk-pltu-diperkirakan-naik-ke-113-juta-ton.

Utami, S. S. (2020) Ekspor Batu Bara ke Negara Berkembang Masih Menjanjikan, www.medcom.id. Available at: https://www.medcom.id/ekonomi/bisnis/Rb1mX5zb-ekspor-batu-bara-ke-negaraberkembang-masih-menjanjikan. 